\title{
Film: Time capsule
}

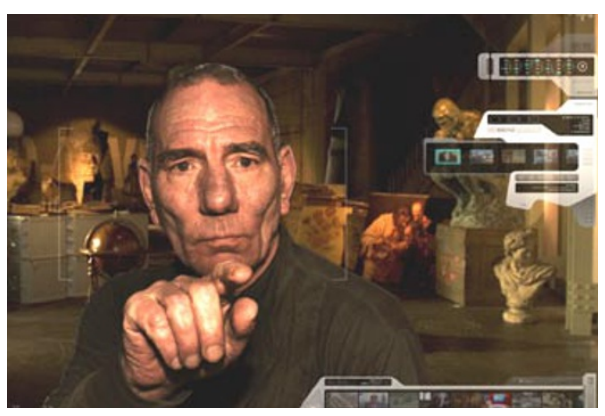

Hindsight is 20/20, and looking back from a global catastrophe ought to make it sharper still. Small comfort for survivors, like The Age of Stupid's narrator. On a ruined Earth in 2055, holed up in the fortress-like Global Archive, the film's fictional guide - played with gravitas by Pete Postlethwaite - trolls back through actual news clips and documentary footage captured 50 years earlier, trying to find out what went wrong.

Back here in the 2000s, the more talk there is about curbing greenhouse gas emissions, the more they continue to grow. In a poll by the Washington DC-based Pew Research Center last month, Americans ranked climate change as the lowest priority on a list of 20 problems. There's no knowing yet whether society will change its course in time to avoid the worst impacts of global warming. But for Postlethwaite's archivist, the only remaining question is why we failed to save ourselves. The Age of Stupid taps into this retrospection to explore how today's world is facing up to its uncertain future.

The film's most direct answers about what's delaying the response to climate change come in brisk, spunky animations fingering Big Oil, consumerism and global inequity. But its documentary strands are focused at much closer range, on several more or less ordinary people. There's a Nigerian would-be doctor in a Shell Oil-dominated village; an American paleontologist working for Shell who lost everything in Hurricane Katrina; an Indian tycoon starting the country's first low-cost airline; refugee Iraqi children who mend and resell Westerners' discarded shoes; a wind-farm planner battling the recalcitrant local council in Britain; and the oldest mountain

\section{THE AGE OF STUPID}

Spanner Films: 2009

\section{Will future generations condemn our sluggish response to climate change?}

guide who still climbs the deglaciating French Alps.

This is not a climate science documentary. Director Franny Armstrong has credited Al Gore's An Inconvenient Truth with bringing filmgoers up to speed on the problem of climate change. Indeed, the archivist's mournful shuffling through TV news fragments suggests how many times the audience has probably heard that human-caused emissions are warming the planet.

Scenes set in 2055 impressionistically depict the fallout from unchecked emissions: with communities unable to adapt, drought leads to food riots, and swollen storm surges drown an unprepared London. The film makes clear from the start that these images are "based on mainstream science predictions", but unlike similarly vivid visions in the book Six Degrees by journalist Mark Lynas - who served as an advisor for The Age of Stupid - this one leaves out the footnotes and caveats, which would otherwise explain the likelihood of such events occurring.

One awkward result of avoiding scientific precision is a mixed message on the significance of recent extreme weather. Hurricane Katrina, for example, appears as an early entry on the Archive's index of "major climate change events" - an enviable but logically impossible list. Scientist Sir David King does point out in one of the archival news clips that single events can't fairly be attributed to climate change, clashing with the archivist's certainty.

But the movie is about our reactions to climate change, not the Earth's. Its futurism is a framing device designed not to convey the science of climate impacts, with its many contingencies and broad uncertainties, but to draw attention sharply to the present. And it's in the six contemporary storylines that the movie hits its depth.

The wonderfully creative Armstrong, whose past films include McLibel and Drowned Out, largely avoids talking heads, lengthy BBC-accented voiceovers, and other stifling staples of many documentaries. The pace is taut and the portraits intimate and playful, with an eye for gem-like moments of absurdity. The footage flatters some of its subjects more than others, especially favouring the climate-conscious, but all are allowed to speak for themselves and their way of life. And where the archivist's views are uncompromising - "What state of mind were we in," he demands, "to face extinction and simply shrug it off?" - these stories connect up in complex and sometimes contradictory ways.

Take oil, the major bad guy. In Nigeria, Shell pumps tens of millions of dollars out of the ground weekly while leaving the locals in poverty; the young woman saving for medical school finds she can make more money bootlegging diesel than fishing in the oil-slicked river. Oil is blamed for the war that killed the Iraqi kids' father, though they themselves think Americans are the evil cause. But the American oil man on screen is a soft-spoken scientist and lifesaving New Orleans hero who reveres the usefulness and beauty of the black stuff. One of the film's most likeable people, he also makes its most convincing argument for conservation.

Armstrong says she hopes that the film will reinvigorate the clichéd 
question, "What are we leaving our children?” But a superficial glimpse into mid-century doesn't add much oomph in that department. The question the film actually hammers home is "How will history judge us?" In one sequence, the environmentalist and author George Monbiot argues that living when a known crisis must be confronted makes us "tremendously powerful people".
The filmmakers make the case that we, the powerful, should consider how our choices affect the atmosphere - the film's carbon footprint rolls after the credits - whether by direct individual action or government regulation. When we look back on our present window of opportunity, The Age of Stupid suggests, we might prefer to at least appear as though we'd made an effort.
Published online: 5 February 2009

doi:10.1038/climate.2009.14

Anna Barnett

Anna Barnett is assistant editor and copy editor of Nature Reports Climate Change. e-mail:a.barnett@nature.com

The Age of Stupid opens in the UK on 20 March 2009 and internationally in May 2009 (http://www.theageofstupid.net).

\section{nature}

\section{geoscience}

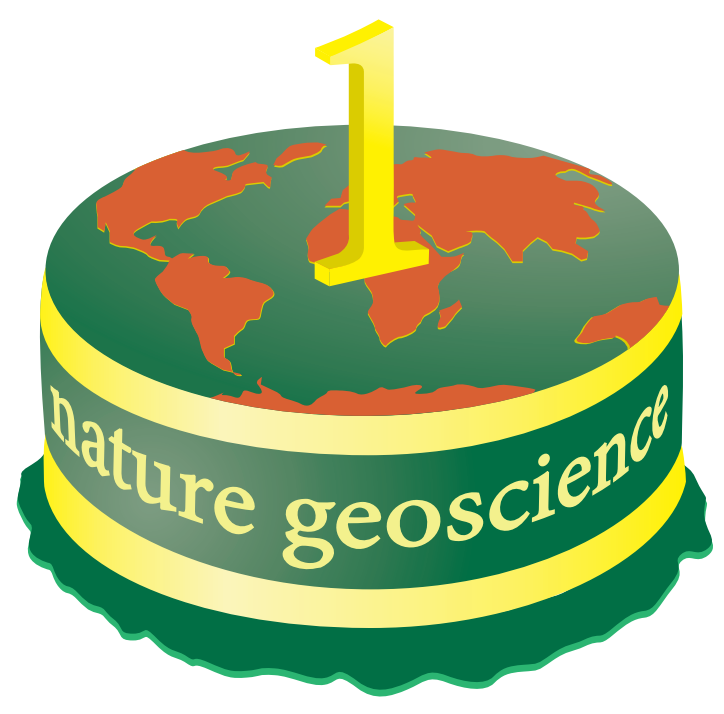

www.nature.com/naturegeoscience

\section{Celebrating its first anniversary}

January 2009 marks the first anniversary of the launch of Nature Geoscience. To celebrate, the editors have put together their favourite articles from the first 12 issues. This selection is free to view online for the months of January to March and reflects the breadth of topics and the diversity of article styles covered by Nature Geoscience.

Visit this first anniversary site at www.nature.com/ngeo/focus/anniversary/ to obtain free access to the selected articles. 